ROCZNIKI TEOLOGICZNE

Tom LXVI, zeszyt $7 \quad 2019$

DOI: https://dx.doi.org/10.18290/rt.2019.66.7-10

IRENA SASZKO

\title{
ŚWIATŁOŚĆ NIESTWORZONA W REFLEKSJI TEOLOGICZNEJ METROPOLITY SUROŻSKIEGO ANTONIEGO (BLOOMA)
}

\author{
UNCREATED LIGHT \\ IN THE THEOLOGICAL REFLECTION OF METROPOLITAN \\ ANTHONY OF SOUROZH (BLOOM)
}

\begin{abstract}
The present article concerns the theological reflection of Metropolitan Anthony of Sourozh (Bloom) on the subject of the Uncreated Light. At the moment of the fall of our first parents, man lost the ability to participate directly and fully in the uncreated Energies of the Divine Light and for this reason he can only know the mystery of God "in twilight," that is in an apophatic manner. From the fact of the creation of the human person in the image and likeness of God, it follows that in every man there is the germ of the Divine Light. Thanks to the relationships of love with our fellow men, we are able to discover this Light on their faces. The whole Church shines with the Uncreated Light, because it is the place of the direct presence of God among His people. In the liturgical celebrations of the Orthodox Church, especially in Lauds and Vespers, the faithful anticipate the full participation in the Uncreated Light, which will be their part at the end of time.
\end{abstract}

Key words: Uncreated Light; darkness; deification; the human person; Divine Energies; Lauds; Vespers; Orthodox celebrations.

Zarówno Stary, jak i Nowy Testament obfitują w różnego rodzaju przykłady teofanii Boga jako Światłości: jaśniejące oblicze Mojżesza podczas rozmowy z Bogiem na Górze Synaj (por. Wj 20,21), jasność Krzewu Gorejącego na pustyni (por. Wj 3,1-6), wizja Szczepana - pierwszego męczennika (por. Dz 6,15; 7,55-56), oświecająca św. Pawła światłość na drodze do Damaszku (por. Dz 9,3), a przede wszystkim Przemienienie Chrystusa na Górze Tabor (por. Mt 17,1-8) ${ }^{1}$.

Dr IRENA SASZKO - starszy wykładowca Katedry Filologii Słowiańskiej Chmielnickiego Uniwersytetu Narodowego na Ukrainie; adres do korespondencji — e-mail: irenasaszko@gmail.com.

${ }^{1}$ G.I. MANTZARIDIs, Przebóstwienie człowieka. Nauka świętego Grzegorza Palamasa w świetle tradycji prawosławnej, tłum. I. Czaczkowska, Lublin: Prawosławna Diecezja Lubelsko-Chełmska 1997, s. 101-104. 
Dobra Nowina, głoszona przez św. Jana Apostoła zarówno w Ewangelii, jak i w Pierwszym Liście, jest taka: „Bóg jest światłością, a nie ma w nim żadnej ciemności" (1 J 1,5). Istota Boga jest bardzo prosta. Jest nią Światłość - niestworzona, niezachodząca i niewyczerpująca się, a przede wszystkim „prawdziwa” (por. J 1,9). W owej Światłości nie może być żadnego miejsca na cień czy zmierzch. Jest ona przeźroczysta i olśniewająca. Co więcej, Boska Światłość rozjaśnia wszelkie ciemności. Mroki nocy w jej blasku stają się dniem (por. Iz 58,10; Ps 139,12)². Gdy Światłość w Osobie Wcielonego Słowa przyszła na świat (por. J 1, 1-5), ludzie opowiedzieli się za ciemnością. Wybrali noc rozpaczy zamiast Światłości niezachodzącej, ponieważ pragnęli ukryć swoje „złe uczynki” (J 3,19). Świat jest pełen ciemności, gdyż rządzi nim książę ciemności. Właśnie z tego powodu Chrystus - „Bóg z Boga i Światłość ze Światłości”, jak to jest wyznawane w Credo Nicejsko-Konstantynopolitańskim - rozsyła Swoich uczniów, aby stali się światłością dla ludzi (por. J 8,12; Mt 5, 14-16) ${ }^{3}$.

Temat niestworzonej Boskiej Światłości jest nierozerwalnie związany

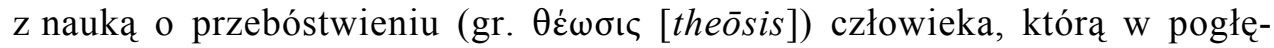
biony dogmatyczny sposób dookreślił św. Grzegorz Palamas (1296-1359), arcybiskup Salonik. Problematyka odnosząca się do Boskiej Światłości stanowiła sedno dysputy teologicznej o niestworzonych Energiach Bożych, toczącej się w XIV wieku w Grecji ${ }^{4}$. Obrońca hezychastów dowodził, że każdy człowiek, dzięki twórczemu współdziałaniu z Bogiem (gr. бvvé $\gamma \varepsilon ı$ [synergeia]), może mieć udział w niestworzonych Energiach Bożej Świa-

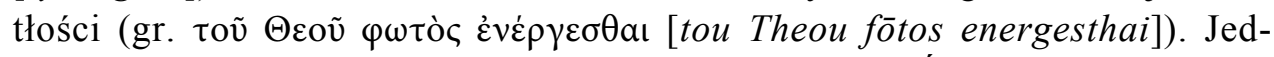
ność z Bogiem dokonuje się za sprawą łaski Ducha Świętego, Jego przebóstwiającego daru ${ }^{5}$. Św. Symeon Nowy Teolog, sam doświadczywszy tego daru, napisał: „Twoja dusza, przyjąwszy łaskę, rozbłyśnie cała, podobnie do samego Boga"6. Owa Światłość, rozumiana jako chwała Ojca i królestwo Syna, jest w istotny sposób powiązana z naturą Boga i stanowi rzeczywiste promieniowanie Jego substancji ${ }^{7}$. Widzenie Boskiej Światłości, które było udziałem niektórych świętych chrześcijańskiego Wschodu, pozwalało im nie

\footnotetext{
${ }^{2}$ Por. P. Evdokimov, Życie duchowe w mieście, thum. M. Żurowska. Poznań: W drodze 2011, s. 49.

${ }^{3}$ Por. MantZARIDIs, Przebóstwienie człowieka, s. 101-105.

${ }^{4}$ Tamże, s. 101.

${ }^{5}$ Por. M. ŁawreszuK, The Role of the Holy Spirit in Human Deification, „Elpis” 18 (2016), s. $22-26$.

${ }^{6}$ Cyt. za: P. Evdokimov, Prawosławie, thum. J. Klinger, Warszawa: Instytut Wydawniczy PAX 1964, s. 126.

${ }^{7}$ Por. Y. SPITERIS, Ostatni Ojcowie Kościoła. Kabasilas. Palamas, thum. B. Widła, Warszawa: Wydawnictwo Księży Marianów 2006, s. 230.
} 


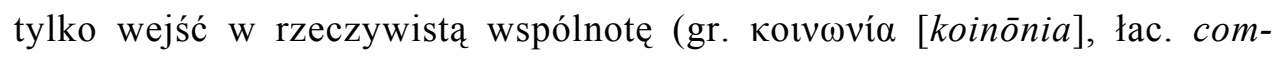
munio) z Bogiem w Trójcy Przenajświętszych Osób, ale również otrzymać

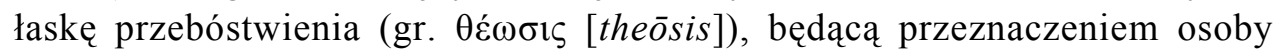
ludzkiej i ostatecznym celem jej egzystencji. Przebóstwienie nie jest bowiem jedynie naśladowaniem Jezusa, lecz ,życiem w Chrystusie”, polegającym na udziale „całego człowieka” w „całym Bogu”. ${ }^{8}$

Zagadnieniem przebóstwiającej Światłości zajmowało się wielu wybitnych prawosławnych teologów9. Spośród nich warto zwrócić uwagę na jednego z najbardziej znanych duchownych prawosławnych XX wieku, lekarza, teologa i ekumenistę, a mianowicie Metropolitę Surożskiego Antoniego (Bloom'a) (1914-2003). Hierarcha ten zasłynął swymi homiliami i kazaniami, w których przybliżał mądrość pochodzącą ze Słowa Bożego i pomagał wiernym w rozwiązywaniu problemów życiowych. Nie był on teologiem w sensie akademickim. Trudno też uznać go za typowego przedstawiciela tradycji hezychastycznej, chociaż był zafascynowany hezychazmem. Jego ojcem duchownym był mnich Monasteru Wałaamskiego, który - jak wspomina sam Metropolita - miał doświadczenie modlitewnego wyciszenia wewnętrznego (gr. j̇ouxia [hēsychia]). Czy owo wyciszenie wewnętrzne było związane z uczestnictwem w niestworzonych Energiach Boskiej Światłości? Trudno jednoznacznie odpowiedzieć na to pytanie. Nie ma jednak wątpliwości co do tego, że doświadczenie duchowe starca wywarło wielki wpływ na refleksję teologiczną Metropolity Antoniego. Warto również pamiętać, że Metropolita Surożski, zanim jeszcze został kapłanem, na polecenie ks. prof. Georgija Fłorowskiego przez kilkanaście lat systematycznie wczytywał się $\mathrm{w}$ teksty hezychastyczne, a jednym $\mathrm{z}$ jego najbliższych przyjaciół był archimandryta Sofroniusz (Sacharow), uczeń św. Sylwana z Góry Athos ${ }^{10}$.

\footnotetext{
${ }^{8}$ J. Meyendorff, Teologia bizantyjska. Historia i doktryna, tłum. J. Prokopiuk, Kraków: Wydawnictwo Uniwersytetu Jagiellońskiego 2007, s. 154-155.

${ }^{9}$ Por. К. КеРн, архим. [Kern Kiprian, arkhimandrit], Антропология св. Григория Паламы [Antropologiya sv. Grigoriya Palam], Париж [Parizh]: YMCA-Press 1950; J. MEYENDORFF, Introduction à l'étude de Grégoire Palamas, Paris: Éditions du Seuil 1959; G.I. MANTZARIDIS, Przebóstwienie człowieka. Nauka świętego Grzegorza Palamasa w świetle tradycji prawosławnej, thum. I. Czaczkowska, Lublin: Prawosławna Diecezja Lubelsko-Chełmska 1997; W. ŁossKIJ, Teologia mistyczna Kościoła Wschodniego, tłum. M. Sczaniecka, Warszawa: Instytut Wydawniczy PAX 1989; НЕЛЛАС П. [NeLlas P.], Обожение: основы и перспективы православной антропологии [Obozheniye: osnovy i perspektivy pravoslavnoy antropologii], перевод Н.Б. Ларионова [perevod N.B. Larionova], Москва: Никея [Moskva: Nikeya] 2011; Y. SpITERIS, Ostatni Ojcowie Kościoła. Kabasilas. Palamas, tłum. B. Widła. Warszawa: Wydawnictwo Księży Marianów 2006.

${ }^{10}$ П. СеРЖАнтов [P. Serzhantov], Исихастская антропология. О временном и вечном [Isikhastskaya antropologiya. O vremennom i vechnom], Москва: Паломник [Moskva: Palom-
} 


\section{MIĘDZY ŚWIATŁEM A CIEMNOŚCIĄ: APOFATYCZNA DROGA POZNANIA BOGA}

Zbiór kazań Metropolity Antoniego (Blooma) z lat 2001-2002 pt. Світло y темряві [Svitlo u temryavi; Światłość w ciemności] ${ }^{11}$, a także jego nauczanie na temat Jutrzni oraz Wieczerni w Kościele prawosławnym ${ }^{12}$ są świadectwem wielkiej pokory mnicha i hierarchy, który swoją drogę poznania Boga porównuje do dziecięcej gry w chowanego ${ }^{13}$. Tak jak do Mojżesza Bóg przemawiał w ciemnym obłoku (por. Wj 20,21), tak też jemu pozwala się poznać niejako po omacku, gdyż ograniczony ludzki umysł jest w stanie uchwycić jedynie odblaski niestworzonego Światła ${ }^{14}$. Powoduje to we wnętrzu człowieka swego rodzaju napięcie, które jest doświadczane jako cierpienie, ponieważ Bóg, niejako wyglądając zza krzewu, nigdy nie pozwala się uchwycić, mimo że od czasu do czasu daje się usłyszeć Jego głos. Wówczas Światłość niestworzona staje się Boską ciemnością. Ilekroć człowiek próbuje na tę Światłość spojrzeć, to traci zdolność widzenia ${ }^{15}$. Można to łatwiej zrozumieć w nawiązaniu do Pieśni nad Pieśniami, w której płonąca żarliwą miłością Oblubienica nieustannie poszukuje swego Umiłowanego, a wyciągając ku Niemu ręce, pragnie objąć Nieogarnionego ${ }^{16}$. Metropolita Antoni przytaczał historię św. Sylwana z Góry Athos (1866-1938), który ponad czternaście lat gorliwie modlił się o doświadczenie i poznanie Boga. Jedynie

nik] 2010. s. 280. Рor. Антоний Сурожский (Блум), митр. [Antoniy Surozhskiy (Blum), mitr.], Tpydы. Книга первая [Trudy. Kniga pervaya], переводы Т. Л. Майданович, Е. Л. Майданович [perevody T. L. Maydanovich, Ye. L. Maydanovich], Москва: Практика [Moskva: Praktika] 2002, s. 769-771, 888-889.

${ }^{11}$ Антоний Сурозький, митр. [ANTONIY SuROZ'KyY, mytr.], Світло у темряві. Останні розмови 2001-2002 pp. [Svitlo u temryavi. Ostanni rozmovy 2001-2002 rr.], переклад Н. Безбородова, Л. Лисенко [pereklad N. Bezborodova, L. Lysenko], Київ: Дух і Літера [Кууіv: Dukh i Litera] 2015.

${ }^{12}$ Антоний Сурожский, митр. [ANTONIY SuROzHSKIY, mitr.], Вечерня. Утреня [Vechernya. Utrenya], перевод Т.Л. Майданович [perevod T.L. Maydanovich], Мосва: Фонд «Духовное наследие митрополита Антония Сурожского» [Moskva: Fond «Dukhovnoye naslediye mitropolita Antoniya Surozhskogo»] 2011.

${ }^{13}$ Por. Антоній СуРОзький, митр. Світло у темряві, s. 10-11.

${ }^{14}$ Por. ВАРФОЛОмій, патріарх [VARFOLOMIY, patriarkh], Віч-на-віч із Тайною. Православне християнство у сучасному світі [Vich-na-vich iz Taynoyu. Pravoslavne khrystyyanstvo u suchasnomu sviti], переклад Д. Морозова [Pereklad D. Morozova], Київ: Дух і Літера [Kyyiv: Dukh i Litera] 201 s. 126-130.

${ }^{15}$ Por. Антоній Сурозький, митр., Світло у темряві s. 11-12.

${ }^{16}$ I. SASZKo, „Rozświetlona przez Świattość Trójsłonecznq”. Relacja Theotokos do Osób Trójcy Przenajświętszej w tradycji liturgicznej Kościoła prawosławnego, Lublin: Prawosławna Diecezja Lubelsko-Chełmska 2014, s. 35. 
wówczas, gdy zmęczony i zrezygnowany zawołał: „Panie, Ciebie nie sposób przekonać!", ogarnęła go niestworzona Światłość Boża — i wtedy doświadczył słodkiej obecności zmartwychwstałego Pana ${ }^{17}$.

Metropolita Antoni nauczał, że Bóg jest Światłością. Im bardziej zbliżamy się do niej, tym głębiej doświadczamy naszych ludzkich ograniczeń. Tego bowiem, który zamieszkuje „Światłość niedostępną”, żaden z ludzi nie widział ani zobaczyć nie może (por. 1 Tym 6,16). Owa Światłość jest nieosiagalna, a nawet niewidzialna. Jest ona podobna do „Boskiego diamentu, jaśniejącego niczym gwiazdy na niebie" ${ }^{\prime 1}$. Człowiek z powodu własnej grzeszności nieustannie błąka się pomiędzy Światłością a ciemnością, a jego poznanie jasności Boga jest jedynie widzeniem zmierzchu. Zdaniem Metropolity Surożskiego wszystko, cokolwiek możemy powiedzieć o Bożej miłości, jasności i mocy, jest jedynie namiastką poznania. Nie da się bowiem ludzkim umysłem ogarnąć Szerokości, Długości, Wysokości i Głębokości Boga (por. Ef 3,18-19). W odniesieniu do człowieka Bóg zawsze pozostaje Kimś absolutnie Innym. Nie sposób Go poznać swoim rozumem. Dyskurs intelektualny nie wystarcza, aby opisać Niepoznawalnego. Jego misterium jest niewysłowione, a wszystkie obrazy, które tworzymy w naszej wyobraźni na temat Boga, są jedynie wytworem naszej „dziecięcej” fantazji ${ }^{19}$. „Ciagle powtarzamy, że Bóg jest Miłością, czy jednak cokolwiek w ogóle wiemy na temat miłości?" - zastanawiał się Metropolita. Zdumiewał się też wszechmocą Boga: „Rzeczywiście, bardzo łatwo jest powiedzieć, że moc Boża jest bezgraniczna. A jednak Wszechmogący Bóg dla zwycięstwa nad złem oddaje na śmierć własnego Syna!”20. Zarówno samego Boga, jak też Jego miłość Metropolita Antoni nazywa „dramatem”. Wszak miłość Boga jest zupełnie czymś innym niż tylko sentymentalną czułością. Jest ona gotowością Boga, aby ponieść wszystkie konsekwencje aktu stwórczego, jak również wziąć odpowiedzialność za to, co każde konkretne stworzenie uczyni ze swoim życiem. Stwarzając osobę ludzką, Bóg w Trójcy Przenajświętszych Osób otwiera Swe objęcia, aby miłować człowieka i mu służyć. Dla Metropolity Blooma jest to na tyle wielka tajemnica wiary, że wszelkie próby ogarnięcia jej ludzkim rozumem są daremne. Przed nią należy jedynie uklęknąć w duchu wdzięczności i uwielbienia. Z tego też względu potrzebujemy Światłości niestworzonej, która będzie coraz bardziej rozjaśniać

\footnotetext{
${ }^{17}$ Por. Антоній Сурозький, митр., Світло у темряві, s. 6-7.

18 Tamże, s. 35.

${ }^{19}$ Tamże s. 16-35.

${ }^{20}$ Tamże s. 35.
} 
mroki naszego ludzkiego poznania, a także uchyli nam przynajmniej rąbek misterium miłości Boga do człowieka. ${ }^{21}$

Stwarzając cały wszechświat ex nihilo, Bóg zanurzył wszystko w Swojej Światłości. Cały Kosmos został ogarnięty Jego miłością. A Stwórca nie przestawał wołać do wszystkich stworzeń: „Przyjdź! Kocham cię!”, nadając im przez to wyjątkową i niepowtarzalną tożsamość. Na początku nie było niczego innego oprócz Boskiej Światłości, miłości, piękna i radości, albowiem wszystkie stworzenia trwały $\mathrm{z}$ Nim w komunii/wspólnocie (gr.

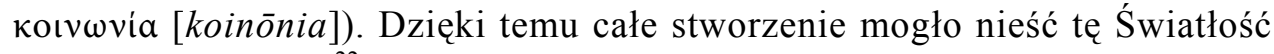
i nią promieniować ${ }^{22}$. Z chwilą upadku prarodziców, „życie ludzkie zaczęło stawać się coraz krótsze, a śmierć powoli zaczęła zwyciężać (por. Rdz 5,1$6,3)^{\prime 23}$. Dobra Nowina jednak polega na tym, że ostatnie słowo nie należy do śmierci. Grzech, który jest „przejściem z terenu Światłości na teren ciemności” ${ }^{24}$, nie może nas odłączyć od Bożej miłości, gdyż „nasza jedność z Bogiem, nasza relacja z Nim, opiera się nie na naszej miłości, lecz — na Jego miłości" ${ }^{25}$. Grzech zanurzył świat w zmierzchu, który Metropolita Antoni definiuje jako stan ponownego żmudnego dorastania do Światłości, kiedy na końcu czasów Chrystus - Światłość świata (por. J 8,12) na nowo stanie się „wszystkim we wszystkich” (1 Kor 15,28) ${ }^{26}$. Wzejdzie On jako Słońce sprawiedliwości, aby wszyscy czczący Jego Imię mogli otrzymać uzdrowienie w Jego promieniach (por. Ml 3,20).

Z Księgi Rodzaju dowiadujemy się, że w Edenie, oprócz Drzewa Życia, Bóg umieścił również Drzewo Śmierci, czyli Poznania dobra i zła, które Metropolita Antoni nazywa „Drzewem poszukiwania przez ludzkość alternatywnej drogi swojego spełnienia i wspólnoty z Bogiem" (por. Rdz 2,8-9.16$17)^{27}$. Powołując się na św. Ireneusza $z$ Lyonu, Hierarcha stwierdza, że Owocem z Drzewa Życia było poznanie Boga poprzez całkowite i bezpo-

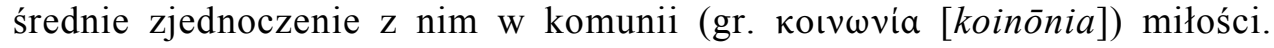
Natomiast owocem z drzewa Poznania dobra i zła była również możliwość poznania Boga, dzięki coraz głębszej jedności ze światem stworzonym. Jest to niejako droga okrężna, wymagająca wielkich starań i cierpliwości, aby coraz bardziej odkrywać Boga i Jego tajemnicę w stworzeniach. Metropolita

\footnotetext{
${ }^{21}$ Por. tamże, s. 36-53.

${ }^{22}$ Por. tamże, s. 132-133.

${ }^{23}$ Tamże, s. 117.

${ }^{24}$ Por. tamże, s. 110.

${ }^{25}$ Tamże, s. 117.

${ }^{26}$ Por. tamże, s. 148, 155.

${ }^{27}$ Por. tamże, s. 85-86.
} 
Bloom porównuje ją do sposobu poznania artysty malarza. Można więc poznać go osobiście, a można też obserwując jego obrazy ${ }^{28}$. Ewa zapragnęła zrozumieć świat stworzony za pomocą własnych ludzkich wysiłków, a nie dzięki relacji z Bogiem. Boga zaś zaczęła poznawać poprzez coraz głębsze odkrywanie tajemnic świata materialnego ${ }^{29}$. Na skutek tego ludzkość utraciła jasność widzenia, którą umożliwia jedynie zjednoczenie z Boską mądrością. „Całe stworzenie ogarnął zmierzch, w którym z jednej strony jest Światłość, z drugiej zaś - ciemność zamieszania" ${ }^{\text {"30 }}$. Dając człowiekowi prawo wyboru, Bóg w Swej miłości nie pozostawił go bez nadziei, która w swej istocie promieniuje światłem, stając się gwarancją osiągnięcia ostatecznego celu.

Metropolita Surożski wciąż uważa za możliwe korzystanie z owoców Drzewa Życia przez osobę ludzką. Wszak tym Drzewem stał się dla nas Krzyż Zbawiciela. Dzięki ofierze paschalnej Syna Bożego ${ }^{31}$, droga do komunii (gr. אoıvwvía [koinōnia]) ze Stwórcą na nowo została otwarta ${ }^{32}$. Można ją osiagnąć poprzez erotyczną relację człowieka do Boga, czyli „dynamiczne pragnienie miłowania" Go ${ }^{33}$ oraz ekstatyczny ruch w kierunku całkowitego zjednoczenia z Nim poprzez modlitwę serca ${ }^{34}$. Głębokie życie duchowe chrześcijanina - zdaniem Metropolity Antoniego — powinno cechować się przede wszystkim umiejętnością rozróżniania światła i ciemności, aby przedzierając się przez zmierzch, móc nieustannie dążyć ku Światłości, a przez

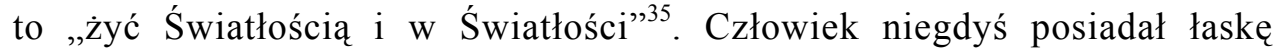
całkowitego uczestnictwa w Światłości niestworzonej, chociaż na pewnym etapie swojej historii „nie zdołał jej utrzymać”. Obecnie coraz jaśniejsze widzenie Boskiej Światłości umożliwia jedynie bezgraniczna ufność Bogu, która nawet $\mathrm{w}$ chwilach całkowitej ciemności nie pozwoli człowiekowi oddalić się od Niego ${ }^{36}$.

${ }^{28}$ Tamże, s. 73.

${ }^{29}$ Por. tamże, s. $60,101-102$

${ }^{30}$ Tamże, s. 95.

${ }^{31}$ Por. tamże, s. 80.

${ }^{32}$ Por. tamże, s. 95-96.

${ }^{33}$ K. LeŚNIEWSKI, „Kim jest człowiek, że o nim pamiętasz..? Podstawowe idee współczesnej antropologii prawosławnej, Lublin: Prawosławna Diecezja Lubelsko-Chełmska 2015, s. 36.

${ }^{34}$ Por. Антоній Сурозький, митр., Світло у темрявi, s. 61. Por. Ch. YAnNARAs, Person and Eros, transl. N. Russel, Brookline, MA: Holy Cross Orthodox Press 2011, s. 16-20; K. Ch. Felmy, Wspótczesna teologia prawosławna, tłum. H. Paprocki, Białystok: Prawosławna Diecezja Białostocko-Gdańska 2005, s. 53.

${ }^{35}$ АнтонІй СурОзький, митр., Світло у темряві, s. 186.

${ }^{36}$ Por. tamże, s. 200. 


\section{ROZŚWIETLONE OBLICZE BLIŹNIEGO. MISTERIUM OBECNOŚCI BOGA W DRUGIM CZŁOWIEKU}

Cały wewnętrzny świat osoby ludzkiej odzwierciedla się na jej obliczu, a dokładniej - w głębokości spojrzenia i jasności uśmiechu. Albowiem „lampą ciała jest oko [...]. Jeśli więc całe ciało będzie rozświetlone, nie mając w sobie żadnej części ciemnej, całe będzie rozświetlone, jak gdyby lampa oświecała go swoim blaskiem" (Łk 11,34.36). Człowiek sam z siebie nie jest źródłem niestworzonej Światłości. Światłość ta jest jedynie w Bogu w Trójcy Przenajświętszych Osób, gdzie „Ojciec jest Słońcem, Syn - Światłością, a Duch Święty - wszystko przenikającym żarem"37. Im bardziej człowiek zbliża się do Światłości, jaką jest Bóg, tym głębiej zostaje przeniknięty blaskiem Jego chwały. W dziejach chrześcijaństwa było wiele osób, z których promieniowała olśniewająca Światłość Boskiej obecności ${ }^{38}$. Obecnie również są kobiety i mężczyźni, a nawet dzieci, którzy trwają w tak głębokim zjednoczeniu z Bogiem, że potrafią w Świetle Jego Słowa spoglądać na wszystkie

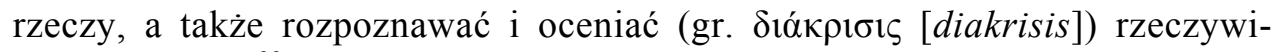
stości duchowe ${ }^{39}$. Tacy ludzie w szczególny sposób napełnieni są łaską Ducha Świętego, choć noszą ją w glinianych naczyniach swojej ludzkiej kondycji ${ }^{40}$. Metropolita Antoni zachęca do podziwiania niezliczonych zastępów świętych zarówno chrześcijańskiego Wschodu, jak i Zachodu, a także do kontemplowania na ich obliczach Boskiej Światłości i miłości ${ }^{41}$. Cały Kościół jaśnieje Światłością niestworzoną, gdyż ,jest miejscem bezpośredniej obecności Boga pośród Swego Ludu. Dzięki Wcieleniu, Bóg stał się częścią świata stworzonego i wniósł w niego Swoją Światłość niezachodzącą"42. Im głębiej jednoczymy się z Chrystusem w Jego Słowie oraz w Eucharystii, tym pełniej stajemy się uczestnikami niestworzonego Światta ${ }^{43}$.

${ }^{37}$ Tamże, s. 168-169. Za św. Grzegorzem Palamasem Metropolita Surożski nauczał, że w Trójjedynym Bogu znajdują się Aniołowie jako „wtórne światła”. Światłość, którą jaśnieją, nie pochodzi od nich, lecz jest Światłością Boga. Oni jednakże, będąc całkowicie otwarci na Boga i przeźroczyści dla Niego, stają się jak gdyby Jego witrażami. Natomiast jeden Anioł, najbardziej jaśniący Bogiem, o imieniu Lucyfer, tzn. niosący światło, w pewnej chwili zachwycił się własnym blaskiem, przyswajając go sobie. Dlatego został ukarany strąceniem do piekła. Por. tamże, s. 82, 148. Por. MANTZARIDIS, Przebóstwienie człowieka, s. 101.

${ }^{38}$ Por. Антоний Сурозький, митр., Світло у темряві, s. 95.

${ }^{39}$ Por. tamże, s. 63.

${ }^{40}$ Por. tamże.

${ }^{41}$ Por. tamże, s. 137.

${ }^{42}$ Tamże, s. 138.

${ }^{43}$ Por. tamże s. $138-139$. 
Dzięki obecności Kościoła w świecie cała ziemia jest napełniona Boskim Światłem. Nie ma takiego miejsca, którego nie dosięgnąłby jego blask. Nie ma też żadnego człowieka, którego nie dotknęłyby jego promienie. ${ }^{44}$ „Gdybyśmy tylko zechcieli spojrzeć na siebie nawzajem, pamiętając, że w drugim czlowieku, którego być może nawet nie znamy bądź zupełnie nie rozumiemy albo nawet nie lubimy, jest zarodek Światłości? [...]. Gdybyśmy tylko spróbowali spojrzeć na siebie w tej Światłości, odkrylibyśmy odwieczną prawdę: «Ten, kto zobaczył swojego brata, zobaczył samego Boga»"45. Za abp. Albertem van der Mensbrugghe Metropolita Antoni głosił, że „cały świat jest przestrzenią bezgraniczną, pośrodku której jaśnieje świeca, podobna do Krzewu Gorejącego z wizji Mojżesza. Jest to Światłość, ogień, ciepło i Objawienie. Nawet jeżeli nie potrafimy jej odczuć, owa Światłość nie przestaje rozlewać się i przenikać ciemności. Właśnie z tego powodu nigdy nie powinniśmy wątpić $\mathrm{w}$ tych ludzi, którzy przebywają w mroku. Boska Światłość na pewno dosięga również ich serca i je dotyka"46.

Co więcej, Metropolita Surożski, w nawiązaniu do słów Zbawiciela, że Bóg oświeca Swoim Światłem zarówno dobrych, jak i złych (por. Mt 5, 44$46)^{47}$, łączy Światłość z miłością. Im bardziej człowiek jednoczy się w miłości z Bogiem oraz z innymi ludźmi, tym głębiej zostaje przeniknięty Światłością niezachodzącą. Aby jednak prawdziwie kochać, należy całkowicie zapomnieć o sobie i odnosić się do drugiego człowieka z wielkim szacunkiem. W swej istocie prawdziwa miłość zawsze jest gotowa do oddania swego życia za bliźniego ${ }^{48}$. A zatem „nikt nie jest w stanie zrozumieć, czym jest miłość, zanim jej nie doświadczy. Nikt też nie jest w stanie pojąć znaczenia całkowitego oddania siebie, dopóki w swoim życiu nie spotka się z ofiarnością. Podobnie też słów Pisma nie da się zrozumieć za pomocą

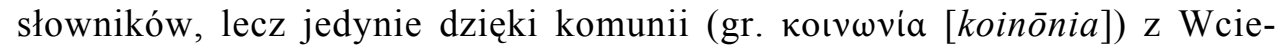
lonym Logosem"49. W związku z tym, aby móc zobaczyć Światłość na obliczu bliźniego, należy ukochać go miłością bezgraniczną, czyli taką, jaką umiłował nas Chrystus (por. J 15, 12). Nie można mówić o miłości, nie wyrażając jej w odniesieniu do innych ludzi, ani mówić o Światłości bez ustawicznego trwania w Prawdzie ${ }^{50}$.

\footnotetext{
${ }^{44}$ Por. tamże, s.139-140.

${ }^{45}$ Tamże, s. 143.

${ }^{46}$ Tamże, s.127-128.

${ }^{47}$ Por. tamże, s. 78.

${ }^{48}$ Por. tamże, s. 151.

${ }^{49}$ Tamże, s.152-153.

${ }^{50}$ Tamże, s. 155.
} 
W swoich rozważaniach o Światłości niestworzonej Metropolita Antoni dość często odwoływał się do przyjaźni między ludźmi. Według niego ludzie stają się przyjaciółmi, łącząc się ze sobą mocą szczególnego rodzaju światłości. Poprzez relację przyjaźni stajemy się uczestnikami tej światłości. „Wówczas możemy przebywać ze sobą, nawet w milczeniu, ciesząc się szczęściem wzajemnej miłości i otwartości na siebie ${ }^{51}$. Podobny charakter ma nasza relacja ze świętymi, którzy są już w Niebie. Oni też są naszymi przyjaciółmi. Zazwyczaj nie potrafimy wyjaśnić za pomocą racjonalnych argumentów, dlaczego przyjaźnimy się z tą czy inną osobą lub zachwycamy się tym czy innym świętym. Odpowiedź okryta jest płaszczem tajemnicy, gdyż niepojmowalne jest misterium zjednoczenia w miłości. Zapewne w człowieku, którego bardzo kochamy, lub w świętym, którego czcimy, jest coś, co porusza nasze wnętrze i czyni nas uczestnikami Światłości, zamieszkującej w tej osobie ${ }^{52}$. „Być może ów człowiek nawet nie poraził nas swoim geniuszem, pięknem czy talentem, ale sprawił, że zajaśniało nam Światło Boga, Światło niestworzonej Boskiej chwały. Jest to coś, co nigdy nie zagaśnie na ziemi" ${ }^{53}$.

Metropolita Antoni zachęcał, abyśmy byli bardzo uważni i odpowiedzialni. Jest tragedią na miarę całego kosmosu, gdy ludzie, zamiast Światłości, wnoszą do życia swoich bliźnich ciemność, a tym samym zwiększają zmierzch, zasłaniają drogę, rozbijają serca ${ }^{54}$. Jeśli natomiast będziemy trwać w miłości Boga, Jego niestworzona Światłość opromieni nas nie tylko od zewnątrz. Ona rozjaśni nas od środka, zamieszka w nas i przemieni. „Gdy Bóg zapali nas, nie spłoniemy, lecz zaczniemy promieniować, stając się światłością i ogniem"55. Strzeżenie w sobie Światłości niestworzonej polega na nieustannym czuwaniu, aby rozświetlać Światłością, która jest w nas, oblicza naszych bliźnich, a także napełniać się ich Światłością, niejako wchłaniając ją w siebie. Wszakże każdy człowiek, którego spotykamy na naszej życiowej drodze, jest odblaskiem Boskiego piękna, w większym lub mniejszym stopniu jest napełniony Boską Światłością, ponieważ został stworzony na obraz i podobieństwo samego Stwórcy. Taki jest sens słów Jezusa, że jesteśmy „światłem świata". Zbawiciel pragnie, aby świeciło nasze światło przed ludźmi, coraz bardziej kierując ich serca ku Bogu (por. Mt 5,14.16).

\footnotetext{
${ }^{51}$ Tamże, s. $100,61$.

52 Tamże, s. 191.

${ }^{53}$ Antoni Bloom, metropolita, Śmierć i rozłaka, w: $W$ drodze ku wieczności, red. K. Leśniewski, W. Misijuk, Lublin: Prawosławna Diecezja Lubelsko-Chełmska 2004, s. 102.

${ }^{54}$ Антоній Сурозький, митр., Світло у темряві, s. 195.

55 Tamże, s. 193.
} 


\section{NABOŻEŃSTWA LITURGICZNE JAKO ANTYCYPACJA PEŁNEGO UCZESTNICTWA W BOSKIEJ ŚWIATŁOŚCI}

W pierwszym rozdziale Ewangelii według św. Jana jest mowa o powołaniu Natanaela (por. J 1,45-51). Wątpiący Izraelita wyznał wiarę w Syna Bożego dopiero wtedy, gdy Mesjasz dotknął najgłębszego sekretu jego serca. Czym jest ów sekret? Co takiego przeżywał Natanael, siedząc pod drzewem figowym? Metropolita Antoni był przekonany, że Natanael był wówczas pogrążony w modlitwie. Słowa Jezusa zatem: „Widziałem cię” (J 1,48) bardzo głęboko poruszyły wnętrze Natanaela. Zrozumiał bowiem, że Bóg ogarnął go Swoim spojrzeniem i usłyszał jego wołanie ${ }^{56}$. Bóg jest bardzo pokorny, gdyż nieustannie pragnie przebywać w naszej obecności, a także pozwala nam przebywać w Swojej obecności. Obecność Boża rozświetla nasz zmierzch, podobnie jak światłość świec rozjaśnia mroki świątyni. ${ }^{57}$

Wyjaśniając znaczenie różnych obrzędów, sprawowanych podczas nabożeństw liturgicznych Kościoła prawosławnego, a zwłaszcza Jutrzni oraz Wieczerni, Metropolita Surożski zwracał uwagę na nieustanną dynamikę, która towarzyszy wszystkim uczestnikom oficjum, gdyż znajdują się w samym sercu „dramatu” i „zanurzają się w całą akcję". Wymaga to od nich

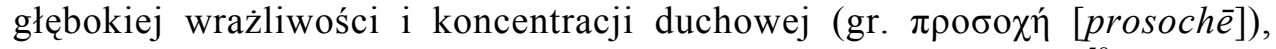
a niekiedy nawet gotowości na zranienie oraz wewnętrzny wstrząs ${ }^{58}$. Ponadto, dokonująca się w cerkwi liturgiczna gra światła i ciemności pomaga uczestnikom nabożeństwa $\mathrm{w}$ przeżywaniu szczególnego rodzaju wewnętrznego napięcia. Światłość bowiem oznacza pełnię obecności Boga, Jego miłości i Objawienia. Ciemność natomiast, z jednej strony, przypomina o ludzkim grzechu i nieprawości, z drugiej zaś skłania do stawiania sobie istotnych pytań egzystencjalnych, które dotyczą samotności, bezradności i cierpienia, sensu życia i śmierci, a także relacji do Światłości niezachodzącej, która jest w Bogu i którą jest Bóg ${ }^{59}$. Może zdumiewać, dlaczego tematem przewodnim wszystkich nabożeństw prawosławnych jest Światłość niestworzona. Objawienie tej Światłości dokonuje się w Chrystusie pośrodku zmierzchu dziejów ludzkości. Z trwaniem w Światłości powiązane jest także oczekiwanie

\footnotetext{
${ }^{56}$ Por. tamże, s. 25-26; 194.

${ }^{57}$ Por. tamże, s. 198.

${ }^{58}$ Антоний Сурожский, митр., Вечерня. Утреня, s. 15-16. Por. А. Филоненко [A. FiLoNENKO], Жизнь для меня Христос. Митрополит Антоний Сурожский [Zhizn' dlya menya Khristos. Mitropolit Antoniy Surozhskiy], Киев: Дух і Літера [Kiyev: Dukh i Litera] 2015, s. 35.

${ }^{59}$ Por. Антоний Сурожский, митр., Вечерня. Утреня, s. 19, 52.
} 
na Paruzję. Wtedy bowiem każdy mrok zostanie opromieniony blaskiem chwały Pana ${ }^{60}$. „Pierwszego dnia stworzenia zostało stworzone światło, a w Zmartwychwstaniu Chrystusa, w pierwszy dzień odnowienia (gr. $\alpha \dot{\alpha} \alpha-$

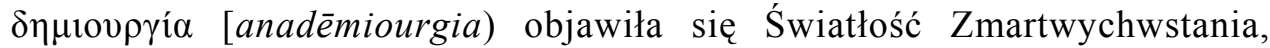
będąca Światłem Przemienienia i Pięćdziesiątnicy"61. Za każdym razem, gdy przed ikonami zostają zapalone świece oraz lampki oliwne, gdy kapłan otwiera bramę królewską i światło zalewa cały ołtarz oraz świątynię, wierni mogą wznieść swoje serca ku Bogu, kontemplując Jego piękno, chwałę i blask. Zdaniem Metropolity Antoniego, nabożeństwa liturgiczne są antycypacją pełnego uczestnictwa Ludu Bożego w niestworzonej Światłości na Godach Baranka, gdzie chwała Boga wszystko oświeci. „I odtąd już nocy nie będzie. A nie potrzeba [będzie] światła lampy i światła słońca, bo Pan Bóg będzie świecił nad nimi, i będą królować na wieki wieków" (Ap 22,5) ${ }^{62}$. Światłość świątyni, otwarcie bramy królewskiej, a także okadzanie ikon oraz wiernych przez kapłana lub diakona zwiastuje nadejście Ósmego Dnia, a więc eschatologiczne, zwycięskie przyjście Pana historii ${ }^{63}$. Gdy zaś kapłan zamyka bramę królewską i wszystkie światła zostają zgaszone, wówczas jedynie lampki oliwne przed ikonami przypominają wiernym, że światłość na obliczach świętych jaśniała nawet $\mathrm{w}$ mrokach tego poranionego przez grzech świata. Te małe światełka są znakiem nadziei dla wszystkich chrześcijan ${ }^{64}$. Bardzo ważną chwilą podczas Wieczerni jest śpiew hymnu „Radosna Światłości”, pochodzącego prawdopodobnie z III wieku. Hymn ten ogłasza zgromadzonym w świątyni wiernym wielką tajemnicę wiary: Niezachodzącą Boską Światłość możemy kontemplować na pokornym i łagodnym Obliczu Bogoczłowieka. W połowie Jutrzni następuje moment uroczystego wniesienia Ewangeliarza, a co za tym idzie - proklamacja Bożego Słowa. Według Prologu Ewangelii według św. Jana (por. J 1,1.4-5) Słowo Boże jest rzeczywistą obecnością Boga pośród Swojego Ludu ${ }^{65}$. Z Ewangelii tryska Światłość niezachodząca, która rozjaśnia cały Kościół ${ }^{66}$. W taki

\footnotetext{
${ }^{60}$ Por. tamże, s. 19-20.

${ }^{61}$ A. POPŁAwSKI, abp., Święta Pascha - Zmartwychwstanie Chrystusa, w: Prawosławie. Światto ze Wschodu, red. K. Leśniewski, Lublin: Prawosławna Diecezja Lubelsko-Chełmska 2009, s. 264.

${ }^{62}$ Por. Антоний Сурожский, митр. Вечерня. Утреня, s. 19-21.

${ }^{63}$ Tamże, s. 45.

${ }^{64}$ Por. tamże s. 28.

${ }^{65}$ „Na początku było Słowo, a Słowo było u Boga i Bogiem było Słowo. W Nim było życie, a życie było światłością ludzi, a światłość w ciemności świeci, i ciemność jej nie ogarnęła" (J 1,1.4-5).

${ }^{66}$ Por. Антоний Сурожский, митр. Вечерня. Утреня, s. 38-39, 50.
} 
sposób przylgnięcie do Słowa Bożego oznacza jedność ze Światłością, a w niej — ze wszystkimi ludźmi na świecie ${ }^{67}$. „Ewangelia głosi, że wszystko, co w naszym życiu zanurzamy w Boskiej Światłości, staje się światłością, a wszystko, co wystawiamy na Światłość, zaczyna nią promieniować" ${ }^{68}$. Ujrzawszy Światłość prawdziwą, wierni powracają do swoich domów, aby zanieść ją swoim bliźnim ${ }^{69}$. Metropolita Antoni przypomina, że wszystkie nabożeństwa prawosławne w misteryjny sposób wznoszą nas na szczyt Taboru, gdzie — podobnie jak Apostołowie — możemy zanurzyć się w kontemplacji blasku Jego chwały i radować się uczestnictwem w Jego niestworzonej Światłości (por. Mt 17,1-8) ${ }^{70}$. Wpatrując się w Oblicze Jezusa, wierni mogą podziwiać tę Światłość, która rozjaśnia Jego Oblicze. „Oblicze Jezusa jest źródłem Światłości. Ono jaśnieje bardziej od Słońca. Jest to Oblicze Paschalne, triumfujące nad bezosobową śmiercią. W nim rozpacz przechodzi w nadzieję (ponieważ Pesach [hebr. חoِgֶ] oznacza przejście). W tym Obliczu wszyscy, którzy utracili swą twarz - upokorzeni, odrzuceni i cierpiący - mogą odnaleźć ją na wieki. Albowiem Twarz Chrystusa jaśnieje Miłością"71.

\section{BIBLIOGRAFIA}

Antoni Bloom, metropolita, Śmierć i rozłąka, w: W drodze ku wieczności, red. Krzysztof Leśniewski, Włodzimierz Misijuk, Lublin: Prawosławna Diecezja Lubelsko-Chełmska 2004.

Антоний Сурожский (Блум), митр. [ANTONIY SUROZHSKIY (BLuM), mitr.], Труды. Книга первая [Trudy. Kniga pervaya], переводы Татьяна Львовна Майданович, Елена Львлвна Майданович [perevody Tatyana L. Maydanovich, Yelena L. Maydanovich], Москва: Практика [Moskva: Praktika] 2002.

Антоний Сурожский, митр. [ANTONIY SuRozhskiY, mitr.], Вечерня. Утреня [Vechernya. Utrenya], перевод Татьяна Львовна Майданович [perevod T.L. Maydanovich], Мосва: Фонд «Духовное наследие митрополита Антония Сурожского» [Moskva: Fond «Dukhovnoye naslediye mitropolita Antoniya Surozhskogo»] 2011.

Антоній Сурозький, митр. [ANTONIY SUROZ'KYy, mytr.], Світло у темряві. Останні розмови 2001-2002 pp. [Svitlo u temryavi. Ostanni rozmovy 2001-2002 rr.], переклад Наталя Безбородова, Леся Лисенко [pereklad Natalya Bezborodova, Lesya Lysenko], Київ: Дух і Літера [Kyyiv: Dukh i Litera] 2015.

${ }^{67}$ Por. tamże s. 54.

${ }^{68}$ Tamże s. 49.

${ }^{69}$ Por. tamże s. 54.

${ }^{70}$ Por. tamże s. 53-54.

${ }^{71}$ О. Клеман. Отблески Света. Православное богословие красоты. Пер. У. Бикбау. Москва: Библейско-богословский институт Св. апостола Андрея 2004 s. 90. Por. Антоний Сурожский, митр. Вечерня. Утреня.., s. 89-90. 
Evdokimov Paul, Prawosławie, tłum. Jerzy Klinger, Warszawa: Instytut Wydawniczy PAX 1964.

Evdokimov Paul, Życie duchowe w mieście, tłum. Maria Żurowska, Poznań: W drodze 2011.

FELmY Karl Christian, Współczesna teologia prawosławna, tłum. Henryk Paprocki, Białystok: Prawosławna Diecezja Białostocko-Gdańska 2005.

Филоненко Александр [FILONENKo Aleksandr], Жизнь для меня Христос. Митрополит Антоний Сурожский [Zhizn' dlya menya Khristos. Mitropolit Antoniy Surozhskiy], Киев: Дух і Літера [Kiyev: Dukh i Litera] 2015.

КеРН Киприан, архимандрит [KERN Kiprian, arkhimandrit], Антропология св. Григория Паламы [Antropologiya sv. Grigoriya Palamy], Париж [Parizh]: YMCA-Press 1950.

КЛЕмАн Оливье [KLEMAN Oliv'ye], Отблески Света. Православное богословие красоты [Otbleski Sveta. Pravoslavnoye bogosloviye krasoty], перевод Ульяна Бикбау [perevod Ul'yana Bikbau], Москва: Библейско-богословский институт Св. апостола Андрея [Moskva: Bibleysko-bogoslovskiy institut Sv. apostola Andreya] 2004.

LEŚNIEWSKI Krzysztof, „Kim jest człowiek, że o nim pamiętasz..? Podstawowe idee współczesnej antropologii prawosławnej. Lublin: Prawosławna Diecezja Lubelsko-Chełmska 2015.

ŁaWreszuk Marek, The Role of the Holy Spirit in Human Deification, „Elpis” 18 (2016) s. 21-26.

ŁosskiJ Władimir, Teologia mistyczna Kościoła Wschodniego, tłum. Maria Sczaniecka, Warszawa: Instytut Wydawniczy PAX 1989.

ManTZARIDIS Georgios I., Przebóstwienie człowieka. Nauka świętego Grzegorza Palamasa w świetle tradycji prawosławnej, tłum. Iga Czaczkowska, Lublin: Prawosławna Diecezja Lubelsko-Chełmska 1997.

MeyendoRfF John, Teologia bizantyjska. Historia i doktryna, tłum. Jerzy Prokopiuk. Kraków: Wydawnictwo Uniwersytetu Jagiellońskiego 2007.

MeyendorfF John, Introduction à l'étude de Grégoire Palamas, Paris: Éditions du Seuil 1959.

НеллАс Панайотис [NeLlas Panayotis], Обожение: основы и перспективы православной антропологии [Obozheniye: osnovy i perspektivy pravoslavnoy antropologii], перевод Н.Б. Ларионова [perevod N.B. Larionova], Москва: Никея [Moskva: Nikeya] 2011.

PopŁawski Abel, abp, Święta Pascha - Zmartwychwstanie Chrystusa, w: Prawosławie. Światło ze Wschodu, red. Krzysztof Leśniewski, Lublin: Prawosławna Diecezja Lubelsko-Chełmska 2009 s. 263-284.

SASzKo Irena, „Rozświetlona przez Światłość Trójsłoneczną”. Relacja Theotokos do Osób Trójcy Przenajświętszej w tradycji liturgicznej Kościoła prawosławnego, Lublin: Prawosławna Diecezja Lubelsko-Chełmska 2014.

СЕРжАнтов Павел [SERZHANTOv Pavel], Исихастская антропология. О временном и вечном [Isikhastskaya antropologiya. O vremennom i vechnom], Москва: Паломник [Moskva: Palomnik] 2010.

SPITERIS Yannis, Ostatni Ojcowie Kościoła. Kabasilas. Palamas, tłum. Bogusław Widła. Warszawa: Wydawnicwo Księży Marianów 2006.

YANNARAs Christos, Person and Eros, transl. Norman Russel, Brookline MA: Holy Cross Orthodox Press 2011.

ВАРФоломій, патріарх [VARFolomIY, patriarkh]. Віч-на-віч із Тайною. Православне християнство у сучасному світі [Vich-na-vich iz Taynoyu. Pravoslavne khrystyyanstvo u suchasnomu sviti], переклад Дарина Морозова [Pereklad Daryna Morozova], Київ: Дух i Лiтера [Kyyiv: Dukh i Litera] 2011. 


\section{ŚWIATŁOŚĆ NIESTWORZONA \\ W REFLEKSJI TEOLOGICZNEJ METROPOLITY SUROŻSKIEGO ANTONIEGO (BLOOMA)}

\section{Streszczenie}

Niniejszy artykuł dotyczy refleksji teologicznej Metropolity Surożskiego Antoniego (Blooma) na temat Światłości niestworzonej. Z chwilą upadku prarodziców człowiek utracił zdolność bezpośredniego i pełnego uczestnictwa w niestworzonych Energiach Boskiej Światłości i z tego powodu może poznawać Jego misterium jedynie „w zmierzchu”, czyli w sposób apofatyczny. Z faktu stworzenia osoby ludzkiej na obraz i podobieństwo Boże wynika, że w każdym człowieku jest zarodek Boskiej Światłości. Dzięki relacji miłości z naszymi bliźnimi możemy odkrywać tę Światłość na ich obliczach. Cały Kościół jaśnieje Światłością niestworzoną, gdyż jest miejscem bezpośredniej obecności Boga pośród Swego Ludu. W nabożeństwach liturgicznych Kościoła prawosławnego, a szczególnie w Jutrzni i w Wieczerni, wierni antycypują pełne uczestnictwo w Światłości niestworzonej, która będzie ich udziałem na końcu czasów.

Słowa kluczowe: Światłość niestworzona; ciemność; przebóstwienie; osoba ludzka; Boskie Energie; nabożeństwa prawosławne; Jutrznia; Wieczernia. 